\title{
Residential Mobility and Homeownership in Dar es Salaam
}

Andreasen, Manja Hoppe; Agergaard, Jytte

Published in:

Population and Development Review

DOI:

10.1111/j.1728-4457.2016.00104.x

Publication date:

2016

Document version

Peer reviewed version

Citation for published version (APA):

Andreasen, M. H., \& Agergaard, J. (2016). Residential Mobility and Homeownership in Dar es Salaam. Population and Development Review, 42(1), 95-110. https://doi.org/10.1111/j.1728-4457.2016.00104.x 
Andreasen M. H. and J. Agergaard (2016): Residential Mobility and Homeownership in Dar es Salaam. Population and Development Review 42(1): 95-110.

https://doi.org/10.1111/j.1728-4457.2016.00104.x. This manuscript is the version accepted for publication in January 2016.

\section{Residential Mobility and Homeownership in Dar es Salaam}

\section{Manja Hoppe Andreasen and Jytte Agergaard}

This article is a study of the intra-urban settlement experiences of residents in the periphery of Dar es Salaam. It emphasizes the importance of homeownership as a key dimension of how migrants and urban-born residents shift their residence within the city boundaries. The evidence suggests that before residents settle in the periphery, they have often lived more than a decade in central and consolidated parts of the city. Many are former migrants, though having become well-established urban residents. Both migrants and urban-born residents often move to the periphery when seeking to establish themselves as homeowners. To a large extent, peripheral residents consider themselves permanent urban residents. The findings suggest that intra-urban residential mobility is a major feature of urban expansion and that the peripheral areas may therefore not function as major arrival areas for new migrants to the city.

Manja Hoppe Andreasen is PhD fellow with the Geography Section, Department of Geosciences and Natural Resource Management, University of Copenhagen.

Jytte Agergaard is associate professor with the Geography Section, Department of Geosciences and Natural Resource Management, University of Copenhagen. 


\section{Residential Mobility and Homeownership in Dar es Salaam}

URBAN POPULATIONS in Africa are growing rapidly, fueled by both natural population increase and substantial inflows of migrants to cities. Urban population growth has largely taken the form of spatial expansion on the urban peripheries (Angel et al. 2011; Arku 2009). Commonly, migration is seen as an important factor in the expansion of urban areas in sub-Saharan Africa, and peripheries are often portrayed as arrival zones for new rural migrants to the cities (Beauchemin and Bocquier 2004; Trefon 2009). This paradigm runs the risk of overlooking the role of intra-urban residential mobility. Entering the city is not the only significant movement: migrants often continue to move around within a given city in search of affordable housing and economic opportunities (Landau 2014). While residential mobility features prominently in analyses of cities in high-income countries, far less is known about intra-urban experiences of urban residents, whether migrants or urban-born, in cities of sub-Saharan Africa (Madhavan and Landau 2011).

This article presents a qualitative study of the intra-urban settlement experiences of current residents of peripheral areas in Dar es Salaam, the largest city and economic capital of Tanzania. Dar es Salaam has experienced continuing rapid population growth. All parts of the city are growing, but none as rapidly as the sprawling peripheral areas, where formerly rural land is being developed and incorporated into the city (Andreasen 2013). Expansion is occurring largely in zones often referred to as unplanned or informal settlements, slums, or squatter areas 
(Kironde 2000, 2006; Kombe 2005). An estimated 80 percent of Dar es Salaam's territory is informal (UN-Habitat 2010a).

We focus on the role of migration and residential mobility in processes of urban expansion. Who are the people populating the periphery? How did they end up living there? Taking residents as the point of inquiry acknowledges their agency and resourcefulness in the transformation of urban spaces undergoing population growth. The new urban neighborhoods that develop, largely informally, on the urban fringes reflect the choices, preferences, and aspirations of residents. Based on a critical reading of the literature on migration, residential mobility, and homeownership, we identify and examine the importance of homeownership as a central aspect of intraurban settlement.

\section{Migrant settlement patterns in cities of sub-Saharan Africa}

Many studies on migrant settlement patterns in African cities indicate that migrants are, to a large extent, populating the growing peripheries. There is some disagreement, though, as to when and why migrants settle in the peripheries. Urban peripheries are often portrayed as arrival zones for new rural migrants. Several older studies documented that in-migration has historically played an important role in driving urban expansion. In an early study of Ibadan, Nigeria, Mabogunje (1962) found that migrants settled primarily in developing peripheral areas, as the central areas were populated by indigenous families and characterized by extreme housing and population density. In a large-scale survey of settlement patterns of migrants in 
Accra, Ghana, Harvey and Brand (1974) found that new migrants mostly lived in peripheral areas, because living space in the central areas had diminished as a result of commercial development and residential crowding. In a study of Benin City, Nigeria, Ozo (1986) found that migrants who arrived in the early 1960s or before first settled in the center, while the majority of later migrants found their first residence in the periphery. Residential space in the central areas had been edged out by commercial development, and land prices and rents in peripheral areas were much more affordable. More recent studies also suggest that urban peripheries are important in absorbing new migrants. A large-scale survey in newly developing peripheral areas of Johannesburg, Maputo, and Nairobi found many new and recent migrants residing in these locations, with more than half of the sample having lived less than ten years in the city (Madhavan and Landau 2011). In a study of Yabello, Nigeria, Aberra (2006) found that new migrants were drawn to the periphery by the possibility of combining rural and urban livelihoods. In a study of two peripheral areas of Dar es Salaam, Kombe (2005) found that one of the areas functioned as a receiving area for new migrants. Access to cheap land, the existence of social ties, and the possibility of engaging in the production of agricultural products for sale in urban markets made this area attractive for the new migrants. A recent large-scale survey of peripheral areas of Dar es Salaam found that 36 percent of residents had migrated directly into one of the peripheral areas from other regions in Tanzania (Ricci et al. 2012). 
In contrast to the above studies, other scholars have found that urban peripheries are not primary arrival zones for new migrants. Rather, these studies suggest that new migrants predominantly settle in already consolidated parts of cities, often finding accommodation with relatives or in rental housing. In a literature review of migration and intra-urban mobility in sub-Saharan Africa, Kliest and Scheffer (1981) found that relatives already living in the cities often played a central role in receiving new migrants. In a study of Lagos, Afolayan (1982) found that 63 percent of migrants initially stayed with relatives or friends. In a more recent literature review of migration and urbanization in Francophone West Africa, Beauchemin and Bocquier (2004) found that new migrants are primarily absorbed in existing urban households, either with relatives or in rental accommodation. Another study estimates that about three-quarters of 1988-2001 new migrants to urban areas in Tanzania joined existing households (Muzzini and Lindeboom 2008). In a study of Lagos, Sawyer (2014) found that new migrants primarily find accommodation in "inner peripheries," consolidated areas around the city center offering cheap rental accommodation close to employment and business opportunities.

The findings from this second group of studies do not exclude the possibility that migrants may settle in the peripheries at a later time. Studies in cities of Latin America highlight the importance of understanding the dynamic nature of migrant settlement over time (Conway and Brown 1980; Gilbert and Ward 1982; Klak and Holtzclaw 1993; Turner 1968; van Lindert 1991; Vaughan and Feindt 1973; Ward 
1976). The Latin American studies emphasize the role of homeownership aspirations in attracting long-term migrants to the peripheries. For migrants, achieving homeownership is part of a wider process of urban integration and permanent urban settlement. A number of more recent studies suggest that similar intra-urban settlement patterns may be found in cities of sub-Saharan Africa. In their literature review of migration and urbanization in Francophone West Africa, Beauchemin and Bocquier (2004) found that residents of peripheral areas have for the most part moved from central parts of the city, though many were originally migrants. In Lagos, Sawyer (2014) found that the periphery is predominantly inhabited by long-term urban residents, though again many were originally migrants. Only dependable and consistent employment would justify the long and costly commutes from these outlying areas, making it unsustainable for new migrants, who are often unemployed. Owens (2010) describes how urban expansion in Dar es Salaam in the 1980s was initiated by urban residents as part of income diversification following the economic crises in the 1970s and 1980s. Originally, they were all rural migrants from various regions, but they had lived and worked in the city for many years before settling in the periphery. In a survey in five settlements in Dar es Salaam, Kironde (2000) found that the majority of landowners in the newly developing peripheral areas originated from elsewhere in Tanzania. In a study of the peripheral area of Mbezi Luisi in Dar es Salaam, Fagerlund (2010) found that the majority of residents originated from outside Dar es Salaam, but had generally lived in other inner-city areas before moving to the 
periphery.

This study traces intra-urban settlement experiences of both migrants and urban-born residents over time. It seeks to clarify and expand the conventional categories of "migrants" and "urban-born" by applying a time- and space-sensitive perspective to migration and residential mobility. In light of its importance in the studies of Latin America cited above, we examine homeownership as a central dimension of how migrants and urban-born residents shift their residence within the city.

\section{Urban growth and the spatial expansion of Dar es Salaam}

Dar es Salaam consists of three administrative municipalities: Kinondoni, Temeke, and Ilala. Combined, the total territory is 1624 sq. $\mathrm{km}$. With a population of 4.4 million in 2012, it is a relatively large city for sub-Saharan Africa (NBS 2013). The population of Dar es Salaam grew at a rapid pace of 5.8 percent per year on average in the most recent inter-censal period from 2002 to 2012 (NBS 2006, 2013). The 2002-2012 growth rate can be compared to the national population growth rate of 2.7 percent for the same period, indicating that approximately half of the city's annual population growth may be attributed to in-migration. Historically, as well, the population of Dar es Salaam has grown much more rapidly than the total population. In 1967-2002 the population of Dar es Salaam grew on average 5.1 percent per year, compared to an average national rate of 3 percent per year (NBS 2006, 2013).

The spatial expansion of Dar es Salaam was noted as a central feature of the 
city already around the time of independence in 1961 (de Blij 1963). Since then the surface area of the city has increased dramatically. While the maximum distance from the center to the edge was $6-10 \mathrm{~km}$ in 1969 , it had risen to $30 \mathrm{~km}$ in the late $1990 \mathrm{~s}$ (Olvera, Plat, and Pochet 2003). Some scholars taking a functional view of the city argue that geographical expansion even extends to 50 or $60 \mathrm{~km}$ in some directions (Halla and Mang'waru 2004; Sawio 2008). Recent population growth has also resulted in widespread spatial expansion. The peripheral parts of the city have grown most rapidly and experienced substantial population increases as well as significant increases in population densities (Andreasen 2013). A considerable increase has been noted, particularly in low-density, discontinuously built-up areas (Macchi et al. 2013). Spatial expansion in the 1970s and 1980s followed a star-shaped pattern along major roads. Growth in the 1990s was characterized by "infill" and densification of linear settlements. Areas to the south across Mzinga Creek experienced far less urban expansion in those years (Briggs and Mwamfupe 2000). The recent expansion has continued this historical pattern, with significant population growth in the areas along and between the main radial roads. Expansion in the southern coastal areas has been more limited than growth in other areas (Andreasen 2013).

\section{Data collection}

This article is based on interviews with migrants in five residential areas, four of which are newly developing peripheral areas and one of which is a formerly peripheral area closer to the center that is today more consolidated. Selection of 
residential areas was based on analysis of spatially disaggregated population data from the two most recent censuses. All of the areas have experienced rapid population growth and substantial increases in population densities during the most recent inter-censal period (see Appendix Table 1 for an overview of the selected residential areas and Map 1 for their locations).

All areas have been transformed from sparsely populated rural or peri-urban areas, dominated by bush and agricultural land use, to more densely developed residential areas forming part of the contiguously built-up urban area. In all areas, urban expansion was initiated by a first wave of newcomers buying land and building houses, predominantly self-constructed, owner-occupied, and single-family. The findings suggest that many of the newcomers are not indigenous to the Dar es Salaam region, but rather migrants and children of migrants originating from other areas of Tanzania. Expansion typically started within smaller villages or scattered settlements inhabited by indigenous residents, broadly referring to members of the Zaramo tribe native to Dar es Salaam and the surrounding coastal region. In un-surveyed areas, expansion was facilitated by informal subdivision and land sales. In the smaller pockets of surveyed land, expansion was facilitated and guided by a formal surveying process. Alongside the homebuilders, many other newcomers were drawn to the areas, preliminarily house caretakers as well as relatives and extended family

\footnotetext{
* Appendix tables and maps are available at the supporting information tab at wileyonlinelibrary.com/journal/pdr.
} 
members of the homebuilders. Later in the process, tenants were also attracted, as some of the homeowners developed parts of their properties into cheap rental accommodation, particularly in un-surveyed areas.

Fieldwork was conducted between November 2013 and May 2014. The core of data on which this article is based consists of semi-structured interviews with 172 residents regarding their settlement preferences and intra-urban settlement histories. The sampling targeted adult household heads paying for housing expenses of their households - that is, land purchase, house construction, rent payments, and so on. In households headed by married couples, either spouse was interviewed depending on availability. Rent-paying tenant households were considered as separate from their landlords' households. A limitation of this sampling is the exclusion of adult dependents, such as young, sick, disabled, or old people, residing in the homes of relatives.

Data collection included focus groups with long-term residents in each residential area, many of whom were indigenous and/or lifelong residents who had been engulfed by the urban expansion. The focus groups aimed to identify changes the areas had undergone during the last 15 years. They were supplemented with ownobservations of the urban environment and interviews with key informants such as local leaders, large investors, and informal land brokers in each area. A total of 29 residents participated in focus groups, while another 29 residents participated as key informants. Data collection was supplemented with interviews with 13 urban planners 
from central planning and service provision agencies and authorities.

\section{Migration and residential mobility: classification of movement}

Migration has both a spatial and a temporal dimension. The simplest and most widely used definition of a migrant is based on change of residence, usually in combination with the crossing of administrative boundaries. This broad definition is used in the 2012 census and results in 52 percent of Dar es Salaam's population being counted as migrants, because they were born outside the Dar es Salaam region (NBS 2015).

If applying the census definition, 122 of the residents in this study could be considered migrants, as they were born outside the Dar es Salaam region, while the remaining 50 were born and raised in Dar es Salaam. This definition raises the question of how long a migrant must reside somewhere to lose migrant status. The great majority of migrants in this study were long-term urban residents who had lived many years in the city. If the most recent previous area of residence is considered, it is possible to distinguish between 23 direct migrants, who settled immediately in a case study area from outside Dar es Salaam, and 99 migrant residential movers, who were originally migrants but moved to a case study area from other parts of the city (Appendix Table 2).

Urban-born residents are also a diverse group. If residents' self-reported region of origin is considered, it is possible to distinguish between those who identified themselves as indigenous to Dar es Salaam and those who identified themselves as originating from elsewhere although they were born and raised in Dar es Salaam 
(Appendix Table 2); 24 residents, all children of migrants, fall into the latter category. When asked about their region of origin, they referred to where their parents were from. They were all residential movers who moved to their current area of residence from other parts of Dar es Salaam. The remaining 26 residents considered themselves indigenous to the Dar es Salaam region. Of these, 13 were residential movers, who moved to their current area of residence from other parts of the city, and 13 were born and have lived their entire lives in their current area of residence. The latter group has effectively been engulfed by urban expansion.

The migration histories of both the direct migrants and the migrant residential movers are characterized by diversity. They originated from all regions of Tanzania and migrated to Dar es Salaam for varying reasons and at different times in their lives. The predominant motives for migrating to Dar es Salaam were work, education, and relationship to other migrants or residents of Dar es Salaam. The differences in motivation were related to the migrants' age at the time of migration (Appendix Table 3). Education was highlighted by those who migrated as children (aged 0-14) or in their youth and young adult ages (aged 15-30), while work was cited by those who migrated in their youth or in adulthood (older than age 30). Many of those who migrated in their youth did so as part of a strategy of becoming income-earning adults. Some moved for a specific job, to work in a particular business, or to learn a trade from a relative. Many of those who migrated in their youth formulated their motivations much more vaguely, though. "Kutafuta maisha," looking for life, is a 
Swahili expression commonly evoked to explain their migration to Dar es Salaam. Those who migrated in adulthood often had more targeted work-related reasons - for example, work transfers within public or private organizations. To join relatives was a common motive among migrants irrespective of their age at migration. Unsurprising, those who migrated as children accompanied their parents or joined relatives residing in Dar es Salaam who would care for them. Seeking support from relatives was commonly mentioned by those who migrated in adulthood, while marriage was more commonly mentioned by those who migrated in their youth and young adult ages.

\section{Categorizing residents' intra-urban settlement experiences}

It was possible to categorize residents according to differences and similarities in their intra-urban settlement histories, their current living arrangements, and their livelihood strategies. Homeownership was an especially important factor in distinguishing categories of residents in relation to their intra-urban settlement experiences. (Residents' intra-urban settlement experiences are summarized in Appendix Table 4; Map 2 illustrates intra-urban settlement trajectories of four selected residents.)

The largest category consists of residents who were homeowners at the time of fieldwork. They were generally older than 30, and 64 out of 92 homeowners were originally migrants born outside Dar es Salaam (Appendix Table 4), though they were generally long-term urban residents with more than ten years of residence in the 
city. All had lived in at least one other residential area before they were able to move into their current home (Appendix Table 5). Previously most of the homeowners lived as tenants or with relatives in the central areas inside and just around the Nelson Mandela Ring Road (Appendix Table 6). Some also lived in consolidated peripheral areas located along the major radial roads, while only a few lived in other newly developing peripheral areas similar in nature to their current residential area. The homeowners generally had well-established, though not always stable, income. Often they had been engaged in the same activities for many years. Among the homeowners were some who were formally employed, as well as some who were self-employed in various informal business and trading activities. Although their income sources were heterogeneous, their ability to establish themselves as homeowners indicates that they did not belong to the poorest segments of the urban population.

Mrs. Mwambene is an example of a homeowner. She is in her early 40s and lives in a small house with her husband and two children. She originates from the coastal region and migrated to Dar es Salaam in her youth to get married (her future husband was already living in the city at the time). She has a small shop outside her house, where she makes and sells fresh chapatti to her neighbors. Her husband runs a small business, buying fresh fruit from farms in the coastal region and selling it at a central market in Dar es Salaam. The family lived in various rental houses in the Mbagala area for many years, but 14 years ago they bought a piece of land and started building a house. Ten 
years ago they were able to move into their own house. They consider their current home to be their permanent residence.

A related category is fast-mover homeowners, who were also adults at the time of fieldwork. The fast-movers were all migrants born outside Dar es Salaam, generally adults when they migrated to the city. The fast-movers were able to establish themselves as homeowners rapidly, either upon arrival or within the first few years after migrating. Some lived a few years as tenants in only one other residential area, predominantly in more central and consolidated areas (Appendix Tables 5 and 6). Some settled directly into their current house from outside Dar es Salaam, because they were able to buy land and construct their house even before migrating, typically with the help of friends or relatives already residing in Dar es Salaam. Likely they were able to draw on resources accumulated in their previous region of residence. The fast-movers tended to have well-established income sources. Most had significant education and were formally employed in the public or the private sector or were formal-sector business owners, indicating that they belonged to the wealthier segments of the population.

Mr. Hamsini typifies a fast-mover homeowner. He is around 50 years old and lives in a large modern house on a surveyed piece of land together with his wife, two daughters, and a housemaid. He is a teacher by profession, but has worked for the Ministry of Education for many years. He originates from the 
Kagera region, but grew up in the Shinyanga region, and has worked for many years in various other regions. Twelve years ago he got posted in Dar es Salaam. He was quickly able to buy a plot of land in Mjimwema through the formal land allocation system and start house construction immediately after migrating. The family lived for a few years in a rented house in the central Sinza area, until they were able to move into their own home. Mr. Hamsini expects to move back to the Kagera region after his retirement and leave the house for his daughters.

A third group consisted of prospective homeowners. At the time of fieldwork they were all in the process of establishing themselves as homeowners, with some in the process of house construction. Others had recently acquired a plot of land or were involved in negotiations to buy a plot. They were on average younger than homeowners and had moved less often (Appendix Table 5). Of the prospective homeowners born outside Dar es Salaam, some were still new or fairly recent migrants, with less than ten years of residence in the city. When they eventually move into their own homes, they are likely to show the same traits characteristic of homeowners. Like homeowners, they generally have well-established, though quite varied income sources.

Mr. Mpinka is an example of a prospective homeowner. He is around 30 years old and lives as a caretaker in a partially built house in Mzinga with his wife, 
two children, and his brother-in-law. He has been taking care of this plot for the last four years while the owner is working in Arusha. Before that he took care of another plot nearby, owned by a friend of his father's. He originates from the Iringa region and migrated to Dar es Salaam ten years ago to be a caretaker of his previous house. Alongside his caretaker responsibilities, he also works as a motorcycle taxi driver. It is dangerous and hard work, but it pays better than his previous work as a casual construction laborer. He has recently bought his own plot in an adjacent peripheral area and expects to start house construction soon. He hopes to be able to move into his own home in a few years.

A distinctly different category is non-homeowners. They all lived in various forms of non-ownership accommodation, primarily as tenants or caretakers. Nonowners were also long-term urban residents who predominantly moved to the periphery from central and consolidated parts of the city (Appendix Tables 5 and 6).

Mr. Habibu is an example of a non-homeowner. He is in his late 30s and lives in a rented room in Br. Mwinyi with his wife and two children. They share the house with four other tenant families. He works as a street trader selling various items such as clothes and jewelry, primarily in central areas like Kariakoo. He originates from the Mtwara region and migrated to Dar es Salaam in his youth in search of livelihood opportunities. At first he lived in a 
relative's home in the central Kurasini area and later found rental accommodation in Br. Mwinyi. He has shifted around between various rental houses in Br. Mwinyi. He thinks that he may have to search for cheaper rental accommodation outside the area soon, as the rents are increasing rapidly in his area. He believes he has to "make his life" in Dar es Salaam and has no expectations of returning home to Mtwara region.

The non-homeowners are an interesting category, because they are mature adults who, like homeowners, have lived for long periods of time in the city. Yet none of them were in the process of establishing themselves as homeowners. This prompts the question of what differentiates homeowners from non-homeowners. It has not been possible to detect any systematic differences between the two categories in relation to their livelihood strategies. Non-homeowners were primarily selfemployed in various informal-sector activities, but so were many of the homeowners. The ability to establish oneself as a homeowner does not seem to be determined by the distinction between formal and informal work. Nor does it seem related to preferences, since most of the non-homeowners expressed a desire to establish themselves as homeowners in the future. This suggests that the ability to establish oneself as homeowner may be influenced by other, less detectable, factors affecting residents' ability to generate income and accumulate savings, such as skills, networks, and social relations. It may also have to do with variable strains on household resources affected by factors like household size, number of younger and 
older dependents, and extended family obligations. However, an in-depth analysis of these differences would have required a different approach.

The remaining residents are indigenous non-movers as well as youths and adult dependents. The indigenous non-movers were all well-established homeowners on inherited land. For the youths and adult dependents there are some quite obvious explanations for why they were not in the process of establishing themselves as homeowners. Some were in their 20s and establishing their own independent incomes, either still living with parents or just recently having moved out of their parents' home. Others were adult dependents living with relatives because they were old or sick.

The intra-urban experiences of migrants were not uniquely different from those of the urban-born. Furthermore, among the migrants, it was not possible to identify any systematic differences in intra-urban settlement patterns in relation to region of origin, age at migration, or motives for moving to Dar es Salaam. All kinds of migration histories are represented across the categories.

\section{Homeownership aspirations as drivers of residential mobility}

The preceding analysis of residents' intra-urban settlement patterns revealed that center-to-periphery residential mobility is a major feature of urban expansion. This section further explores the motivations behind residential mobility. The findings suggest that homeownership aspirations are a central motivation for center-toperiphery residential mobility. The first newcomers buying land and settling in the 
developing peripheral areas were homeowners, who played an important role in fostering urban expansion through purchasing land and building houses. Among the homeowners who participated in individual interviews, the vast majority were firsttime homeowners. They sought the periphery, with its relatively affordable plots, when they wanted to establish themselves as homeowners. Because mortgage finance is almost non-existent in Tanzania, buying a cheap, undeveloped plot of land and building one's own house incrementally is the only way for the vast majority of the population to become homeowners (NHC 2010; UN-Habitat 2010a, 2010b). Buying affordable and undeveloped peripheral land allowed them to construct their own houses over time according to changing income flows.

Social networks were often central in facilitating land transactions. Most homeowners in this study purchased land on the informal market, relying on connections between sellers and buyers. Timing of land purchase was critical. When the sub-division of land first began in the study areas, the un-developed and unserviced nature of the land made it affordable, whereas land prices rose rapidly when infrastructure and services started to improve (Andreasen and Møller-Jensen 2016). The selection of a plot was a crucial step, often involving consideration of possible future development of infrastructure and services as well as protracted negotiations with previous landowners. Both land purchase and subsequent house construction required careful orchestration of household resources and accumulation of savings over an extended period of time. This is part of the explanation for why most of the 
homeowners are long-term urban residents.

Over time the peripheral settlements attracted other types of residents as well. It is common practice among homeowners to have caretakers living temporarily on their property during the construction phase to safeguard it from theft and encroachment. Caretaker families were attracted by the opportunities to live rent-free while homeowners shifted their residence. Relatives and extended family members of landowners were attracted by the possibility of free lodging, a common way of offering support to relatives in much of Tanzania. Later, a second wave of newcomers, consisting primarily of tenants, was attracted. Rental markets emerged, particularly in un-surveyed areas, as some of the homeowners developed parts of their properties into rental accommodation, either subletting a few rooms in the main house or constructing separate tenant houses on their compounds. Non-homeowners were attracted by the rental accommodation, cheaper than that in more central locations. While non-homeowners were not among the first to settle in the study areas, they contributed, through their settlement practices and rent payments to established landowners and homeowners, to the growth and consolidation of these settlements.

A smaller group of residents migrated directly from outside Dar es Salaam into one of the peripheral study areas. Some of them were fast-mover homeowners able to build their own house in Dar es Salaam even before migrating. The main motivation for their migration was work transfers. The rest of the direct migrants either migrated 
in order to live with relatives living in their current residential area or migrated because of specific jobs located in their current area. These findings suggest that the newly developing peripheral areas may not function as primary arrival locations for new migrants in the city. A note of caution, though, is in order as data contain anecdotal evidence of new, younger migrants finding accommodation with relatives who are established as homeowners in the study areas. Given the restriction of our sample to household heads, we have missed this group of migrants in the sampling process for this study. While they were not among the first to settle in the study areas, their presence there indicates that peripheral settlements may become more attractive for new migrants as the settlements grow and consolidate, because of the possibility of finding lodging with relatives who are well established as homeowners.

\section{Permanence and mobility in migrant settlement}

Findings from this study suggest that peripheral areas are inhabited by persons who to a large extent consider themselves permanent urban residents. The majority of both migrants and urban-born residents in this study expected to continue living in Dar es Salaam (Appendix Table 7). While ten of our homeowners considered leaving or planned to leave Dar es Salaam eventually, most of the non-homeowners expected to remain. This is well illustrated by our non-homeowner Mr. Habibu's assertion: "I cannot live in Mtwara. It is the place where I was born and where my family is, but I don't expect to go there for good. Although I am going there to visit family and relatives, I still have to work and make my life here in Dar es Salaam.” Like Mr. 
Habibu, most migrants considered their livelihood to be tied to Dar es Salaam and questioned what they would do if they returned home. Some argued they are too well established in the city. Their children go to school in Dar es Salaam, and their spouse may not even originate from the same region as they do. Some of the older migrants argued that their age and health problems render them unsuited for life in rural areas. Some did not consider they have much to return to, as their parents or relatives may have died. Some simply said that they prefer Dar es Salaam, because of the good environment and the quality of services. Migrants' strong preference for permanent urban settlement may be related to the study's focus on new, rapidly growing peripheral settlements. Targeting more central parts of the city, which would likely include migrants who consider themselves temporary residents, might have yielded different results.

While the majority of residents expected to remain in Dar es Salaam, many also expected to shift their residence within the city. Perhaps not surprising, most of the homeowners and fast-movers considered their current house their permanent residence, as illustrated by our homeowner Mrs. Mwambene's confident response: "For me, this is my permanent place." Interestingly, homeownership does not necessarily equal permanence, as a significant number of the homeowners and fastmovers expected to shift their residence in the future. The fact that they typically considered their houses as permanent family property does not necessarily mean that people are stationary. Some of the homeowners and fast-movers expected to establish 
themselves as second-time homeowners elsewhere in the city, primarily in more peripheral areas. Motives for this included acquiring more living space, living in a "better environment," acquiring space for economic activities, and generating income from subletting their current house. Others expected to leave Dar es Salaam, often to retire after many years of working and living in the city. Some planned to retire on farmland in the nearby coastal region, an option mentioned by both urban-born residents and migrants. A few of the migrants expected to retire "at home" in their region of origin, like our fast-mover Mr. Hamsini: “As long as I work, I will live here, but my expectation is to go home to Bukoba after my retirement. Then I will leave the house for my family, especially my daughters, who are still studying."

The prospective homeowners' future expectations revolved around constructing and eventually moving into their own homes, either within their current residential area or in other newly developing peripheral areas. As our prospective homeowner Mr. Mpinka explained: "I expect to shift from here after two years, if I am still alive. I bought a piece of land quite near to here, and therefore I will start building my house this year. Next year, if God wishes, I will move into my own place." For the non-homeowners, aspirations of homeownership were also an integral part of future settlement considerations. A few of the non-homeowners wanted to leave Dar es Salaam to pursue livelihood opportunities elsewhere, but all of those who wanted to stay in Dar es Salaam expressed a desire to establish themselves as homeowners in the city. Aspiring homeowners will very likely have to look to newer 
peripheral areas for undeveloped land. The more established peripheral areas are strewn with half-finished houses overgrown by vegetation, demonstrating that not everyone may succeed with their house construction projects.

\section{Conclusions}

This article focused on the role of migration and residential mobility in the processes of urban expansion in Dar es Salaam. The evidence indicates that intra-urban residential mobility plays a key role in the city's expansion. Urban residents settle in the periphery predominantly after lengthy urban residence. Before moving to the periphery, residents have often lived for more than a decade in central and consolidated parts of the city, a finding consistent with a number of other studies in sub-Saharan Africa (Beauchemin and Bocquier 2004; Fagerlund 2010; Kironde 2000; Owens 2010; Sawyer 2014). Many are former migrants, though currently wellestablished urban residents.

The findings also suggest that homeownership aspirations are a key motivation for center-to-periphery residential mobility. Many residents moved to the periphery in search of a cheap and undeveloped plot of land on which to construct their houses. Establishing oneself as a homeowner is often a lengthy and cumbersome process, since land purchase and house construction require accumulation of savings over an extended period of time.

Homeowners were the first newcomers settling in peripheral areas, and their land purchases and house construction played an important role in catalyzing urban 
expansion. Urban expansion could be viewed as a manifestation of long-term migrants successfully establishing themselves as homeowners in the periphery along with urban-born residents, whose intra-urban residential mobility is often similar to that of migrants. Peripheral settlements have also attracted residents other than homeowners: first, house caretakers as well as relatives and extended family members; then later tenants, as some homeowners developed parts of their properties into cheap rental accommodation. While these other groups were not among the first to settle in peripheral areas, they contributed to the growth and consolidation of these areas through their settlement practices and, not least, through rent payments to established landowners and homeowners.

This study demonstrates that direct migration is a less important feature in urban expansion than intra-urban mobility. Systematically tracing periphery residents' intra-urban settlement histories reveals that only a few are new migrants into the city. The findings suggest that peripheral areas often are not the primary arrival areas for new migrants in the city (apart from those seeking to live with relatives once the process of development and consolidation is well underway). This conclusion stands in contrast to the many studies, both older and more recent, suggesting that urban peripheries are important arrival zones for new migrants to the cities. Rather, the evidence from Dar es Salaam is more in line with other studies suggesting that new migrants predominantly settle in already consolidated parts of the city and only later move to the periphery. 


\section{Note}

This research is part of the "African Rural-City Connections" (RurbanAfrica) project. RurbanAfrica is funded by the European Union under the 7th Research Framework Programme (theme SSH), Grant Agreement no. 290732. More information can be found at www.rurbanafrica.ku.dk. We thank the residents of Dar es Salaam, who generously gave their time to participate in this research; Professor Robert Kiunsi and Dr. Ally Namangaya from Ardhi University for support and advice; Associate Professor Lasse Møller-Jensen for insightful comments on earlier drafts; John Williams, Christian Maeja, and Sheila Matitu for research assistance; and Kent Pørksen for preparation of maps.

\section{References}

Aberra, Edlam. 2006. "Alternative strategies in alternative spaces: Livelihoods of pastoralists in the peri-urban interface of Yabello, Southern Ethiopia," in Duncan Mcgregor, David Simon, and Donald Thompson (eds.), The PeriUrban Interface. Approaches to Sustainable Natural and Human Resource Use. London: Earthscan, pp. 116-130.

Afolayan, A. A. 1982. "Residential mobility within metropolitan Lagos," Geoforum 13(4): 315-325.

Andreasen, Manja H. 2013. “Population Growth and spatial expansion of Dar es Salaam: An analysis of the rate and spatial distribution of recent population growth in Dar es Salaam," in J. Agergaard (ed.), Rurban Africa Working Papers No. 1, University of Copenhagen. 
Andreasen, Manja and Lasse Møller-Jensen. 2016. "Beyond the networks: Self-help services and post-settlement network extensions in the periphery of Dar es Salaam," Habitat International 53: 39-47.

Angel, Shlomo, Jason Parent, Daniel L. Civco, and Alejandro Blei, M. 2011. "Making room for a planet of cities," in Lincoln Institute of Land Policy (ed.), Policy Focus Report Series. Cambridge, MA: Lincoln Institute of Land Policy. Arku, Godwin. 2009. "Rapidly growing African cities need to adopt smart growth policies to solve urban development concerns," Urban Forum 20(3): 253-270.

Authors. Mimeo. "Suburbanization, homeownership aspirations and urban housing: Exploring urban expansion in Dar es Salaam.” Draft paper.

Beauchemin, Cris and Philippe Bocquier. 2004. "Migration and urbanisation in Francophone west Africa: An overview of the recent empirical evidence," Urban Studies 41(11): 2245-2272.

Briggs, John and Davis Mwamfupe. 2000. "Peri-urban development in an era of structural adjustment in Africa: The city of Dar es Salaam, Tanzania," Urban Studies 37(4): 797-809.

Conway, Dennis and Juanita Brown. 1980. "Intraurban relocation and structure: Lowincome migrants in Latin America and the Caribbean," Latin American Research Review 15(3): 95-125.

de Blij, Harm J. 1963. Dar es Salaam. A Study in Urban Geography, USA:

Northwestern University Press.

Fagerlund, Alexander. 2010. "Living in a peri-urban area as part of a livelihood strategy—The case of Mbezi Luisi, Dar es Salaam," Kulturgeografiska institutionen. Stockholms universitet. 
Gilbert, Alan G. and Peter M. Ward. 1982. "Residential movement among the poor: The constraints on housing choice in Latin American cities," Transactions of the Institute of British Geographers 7(2): 129-149.

Halla, Francos and Walihi Mang'waru. 2004. "Implications of landed and tied-up capital on urban development: The unfinished and unoccupied buildings of Dar es Salaam in Tanzania," Habitat International 28(3): 369-383.

Harvey, Milton E. and Richard R. Brand. 1974. "The spatial allocation of migrants in Accra, Ghana," Geographical Review 64(1): 1-30.

Kironde, J.M. Lusugga. 2000.“Understanding land markets in African urban areas: The case of Dar es Salaam, Tanzania," Habitat International 24(2): 151-165.

_. 2006. "The regulatory framework, unplanned development and urban poverty: Findings from Dar es Salaam, Tanzania," Land Use Policy 23(4): $460-472$.

Klak, Thomas and Michael Holtzclaw. 1993. "The housing, geography, and mobility of Latin-American urban-poor-The prevailing model and the case of Quito, Ecudador," Growth and Change 24(2): 247-276.

Kliest, T.J. and H.R. Scheffer. 1981. "John Turner's theory of intra-urban mobility and the African reality," Tijdschrift Voor Economische En Sociale Geografie 72(5): 258-265.

Kombe, Wilbard Jackson. 2005. "Land use dynamics in peri-urban areas and their implications on the urban growth and form: the case of Dar es Salaam, Tanzania," Habitat International 29(1): 113-135.

Landau, Loren B. 2014. "Conviviality, rights, and conflict in Africa's urban estuaries," Politics \& Society 42(3): 359. 
Mabogunje, Akin. 1962. "The growth of residential districts in Ibadan," Geographical Review 52(1): 56-77.

Macchi, Silvia, Liana Ricci, Luca Congedo, and Guiseppe Faldi. 2013. "Adapting to climate change in coastal Dar es Salaam.” AESOP-ACSP Joint Congress, Dublin.

Madhavan, Sangeetha and Loren B. Landau. 2011. "Bridges to nowhere: Hosts, migrants, and the chimera of social capital in three African cities," Population and Development Review 37(3): 473-497.

Muzzini, Elisa and Wietze Lindeboom. 2008. "The urban transition in Tanzania. Building the empirical base for policy dialogue*."

NBS. 2006. “Tanzania census 2002 analytical report. Vol. X.” Dar es Salaam, Tanzania: National Bureau of Statistics. . 2013. "2012 population and housing census: population distribution by administrative areas." Dar es Salaam, Tanzania: National Bureau of Statistics. . 2015. "Migration and urbanization report," 2012 Population and Housing Census. Dar es Salaam, Tanzania: National Bureau of Statistics Tanzania. NHC. 2010. "Strategic plan for 2010/11-2014/15 (Executive Summary)." Dar es Salaam, Tanzania: National Housing Corporation.

Olvera, Lourdes Diaz, Didier Plat, and Pascal Pochet. 2003. “Transportation conditions and access to services in a context of urban sprawl and deregulation: The case of Dar es Salaam," Transport Policy 10(4): 287-298.

Owens, Geoffrey Ross. 2010. "Post-colonial migration: Virtual culture, urban farming and new peri-urban growth in Dar es Salaam, Tanzania, 1975-2000,” Africa 80(2): 249-274. 
Ozo, A.O. 1986. "Residential location and intra-urban mobility in a developing country: Some empirical observations from Benin City, Nigeria," Urban Studies 23(6): 457-470.

Ricci, Liana, Pietro Demurtas, Silvia Macchi, and Loredana Cerbara. 2012. "Investigating the livelihoods of the population dependent on natural resources and their concerns regarding climate change," ACC DAR Project Working Paper, Sapienza Universitá di Roma, Rome.

Sawio, Camillus J. 2008. "Perception and conceptualisation of urban environmental change: Dar es Salaam City," The Geographical Journal 174: 164-168.

Sawyer, Lindsay. 2014. "Piecemeal urbanisation at the peripheries of Lagos," African Studies 73(2): 271-289.

Trefon, Theodore. 2009. "Hinges and fringes: Conceptualising the peri-urban in Central Africa," in F. Locatelli and P. Nugent (eds.), African Cities: Competing Claims on Urban Spaces. Leiden: Brill, pp. 15-35.

Turner, John C. 1968. "Housing priorities, settlement patterns, and urban development in modernizing countries," Journal of the American Institute of Planners 34(6): 354-363.

UN-Habitat. 2010a. "Citywide action plan for upgrading unplanned and unserviced settlements in Dar es Salaam.” Nairobi, Kenya.

_. 2010b. "Informal settlements and finance in Dar es Salaam, Tanzania." Nairobi.

van Lindert, Paul. 1991. "Moving up or staying down? Migrant-native differential mobility in La Paz," Urban Studies 28(3): 433-463.

Vaughan, Denton R. and Waltraut Feindt. 1973. "Initial settlement and intracity 
movement of migrants in Monterrey, Mexico," Journal of the American Institute of Planners 39(6): 388-401.

Ward, Peter M. 1976. "The squatter settlement as slum or housing solution: Evidence from Mexico City," Land Economics 52(3): 330-346. 


\section{APPENDIX}

\section{Map 1. Location of case study areas}

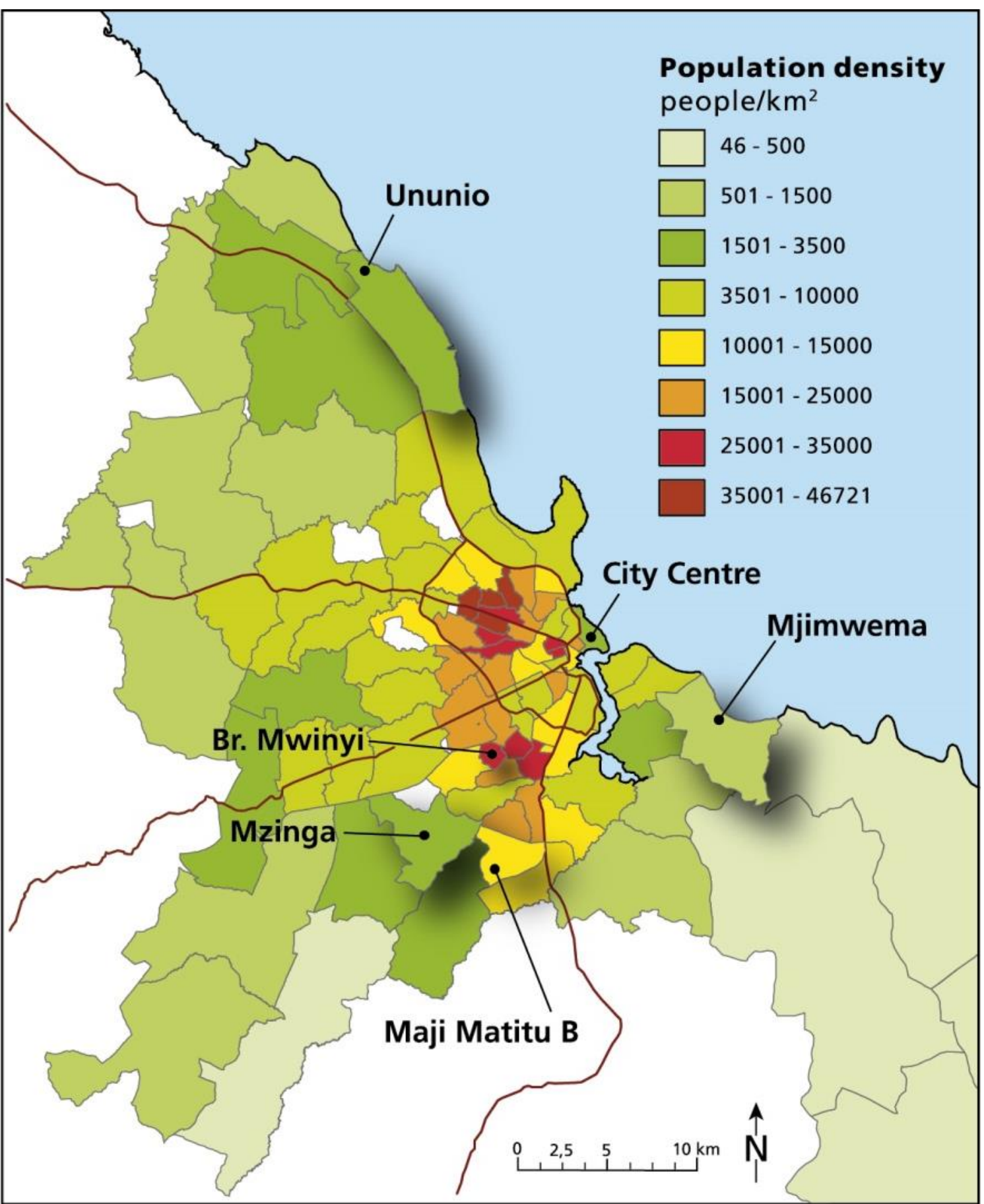

Source: The map shows the approximate locations of the sub-wards selected as case study areas on a thematic map illustrating 2012 population densities across the wards of Dar es Salaam. Population densities have been calculated based on ward-level population counts published as part of the 2012 census (NBS 2013) and ward polygons for Dar es Salaam kindly shared by the National Bureau of Statistics. The thresholds between categories are purposely unequal as they have been carefully selected to visualize variation in the peripheral areas. A note of caution, as the zones are very large in peripheral areas, equal distribution across zones is likely not very representative of the underlying geography of the data. The map is designed by graphic designer Kent Pørksen. 


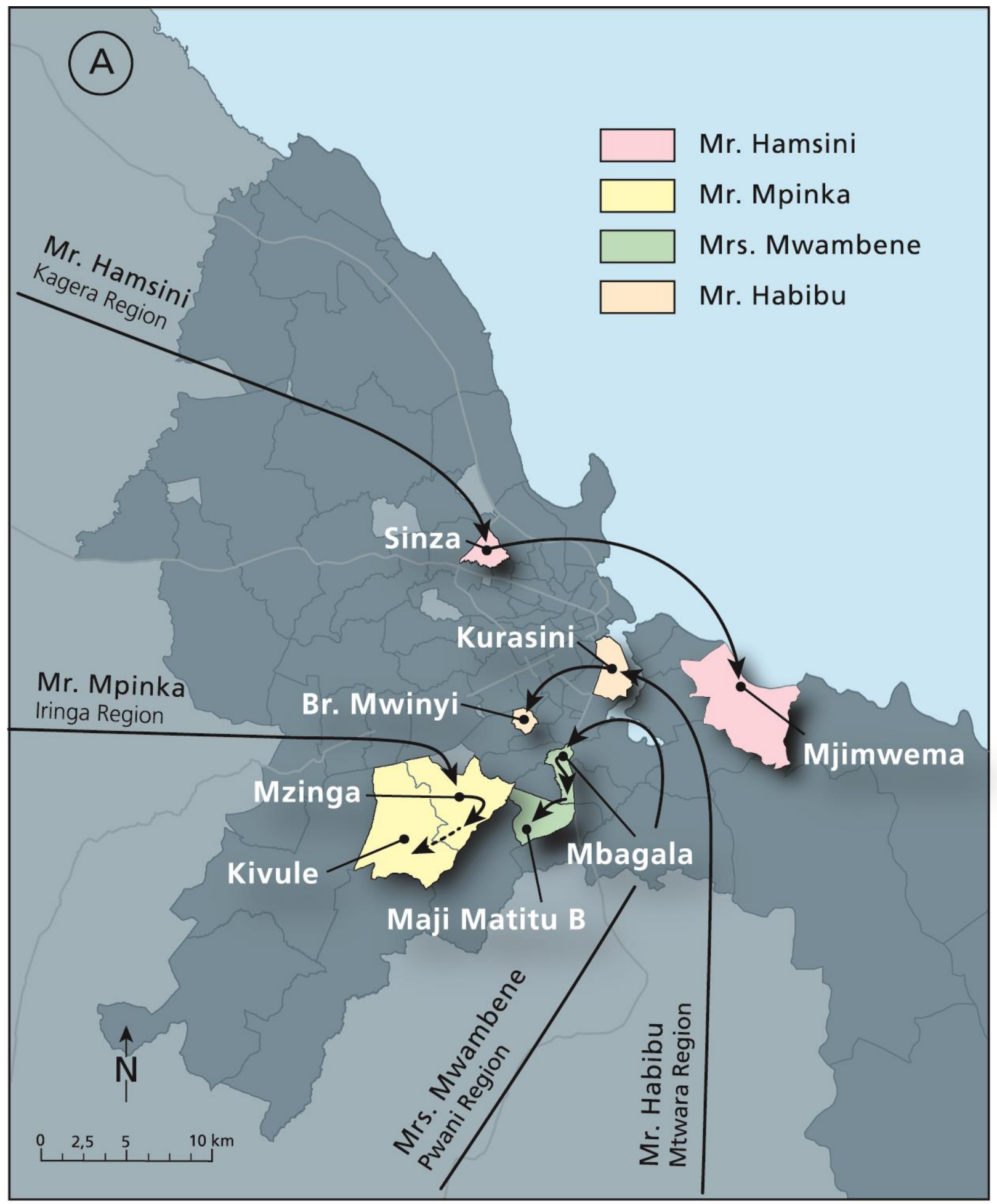




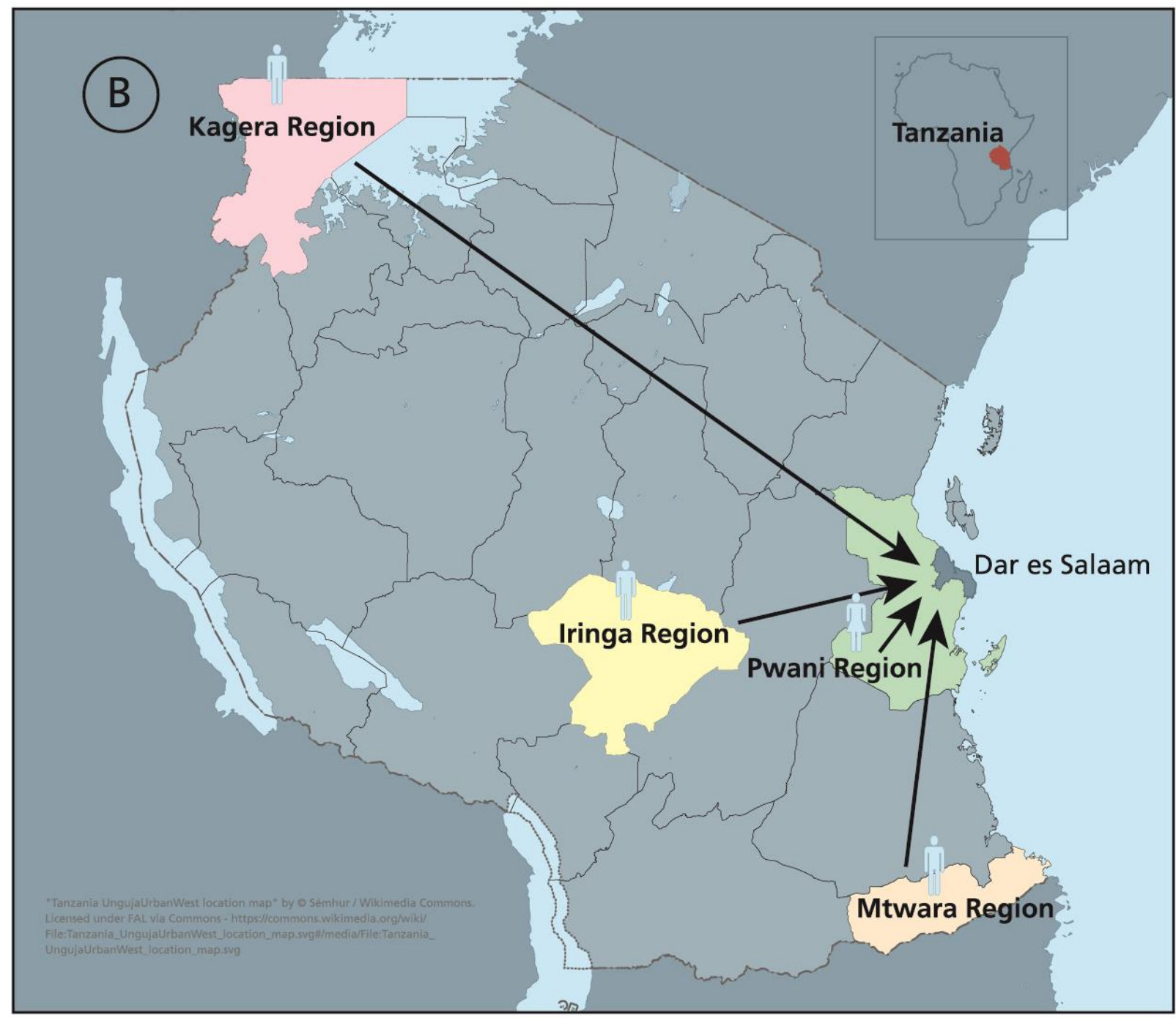

Source: Map A illustrates the intra-urban settlement trajectories of selected residents throughout their time of residence in Dar es Salaam. Map B indicates their regions of origin, though it is not an illustration of their full migration trajectories. The map is designed by graphic designer Kent Pørksen. 


\begin{tabular}{|c|c|c|c|c|c|}
\hline & Ununio & Mzinga & Br. Mwinyi & Mjimwema & Maji Matitu B \\
\hline Income levels & High & Mixed & Low & Mixed & Low \\
\hline $\begin{array}{l}\text { Population } \\
\text { density }\end{array}$ & Low & Low & Very high & Very low & Medium \\
\hline $\begin{array}{l}\text { Status of the } \\
\text { land }\end{array}$ & $\begin{array}{l}\text { Completely } \\
\text { surveyed }\end{array}$ & $\begin{array}{l}\text { Mostly un- } \\
\text { surveyed, with a } \\
\text { small area of } \\
\text { surveyed land }\end{array}$ & $\begin{array}{l}\text { Completely un- } \\
\text { surveyed }\end{array}$ & $\begin{array}{l}\text { Mostly un- } \\
\text { surveyed, with a } \\
\text { small area of } \\
\text { surveyed land }\end{array}$ & $\begin{array}{l}\text { Completely un- } \\
\text { surveyed }\end{array}$ \\
\hline $\begin{array}{l}\text { Dominant } \\
\text { building types }\end{array}$ & $\begin{array}{l}\text { Large single- } \\
\text { family villas }\end{array}$ & $\begin{array}{l}\text { Varying sizes of } \\
\text { single-family } \\
\text { houses }\end{array}$ & $\begin{array}{l}\text { Small single-family } \\
\text { and commercial } \\
\text { houses for tenants }\end{array}$ & $\begin{array}{l}\text { Varying sizes of } \\
\text { single-family houses }\end{array}$ & $\begin{array}{l}\text { Small single-family } \\
\text { houses }\end{array}$ \\
\hline $\begin{array}{l}\text { Start of } \\
\text { subdivision } \\
\text { processes }\end{array}$ & Late 1990 's & Late 1990's & 1980 's & Early 2000's & Early 2000's \\
\hline $\begin{array}{l}\text { Administrative } \\
\text { status }\end{array}$ & $\begin{array}{l}\text { Sub-ward of } \\
\text { Kunduchi Ward, } \\
\text { Kinondoni } \\
\text { Municipality }\end{array}$ & $\begin{array}{l}\text { Sub-ward of } \\
\text { Kitunda Ward, } \\
\text { Ilala Municipality }\end{array}$ & $\begin{array}{l}\text { Sub-ward of } \\
\text { Kilakala Ward, } \\
\text { Temeke } \\
\text { Municipality }\end{array}$ & $\begin{array}{l}\text { Sub-ward of } \\
\text { Mjimwema Ward, } \\
\text { Temeke } \\
\text { Municipality }\end{array}$ & $\begin{array}{l}\text { Sub-ward of } \\
\text { Charambe Ward, } \\
\text { Temeke Municipality }\end{array}$ \\
\hline $\begin{array}{l}\text { Geographical } \\
\text { location }\end{array}$ & $\begin{array}{l}\text { App. } 20 \mathrm{~km} \\
\text { north of the city } \\
\text { center along the } \\
\text { coast }\end{array}$ & $\begin{array}{l}\text { App. } 15 \mathrm{~km} \\
\text { south-west of } \\
\text { the city center }\end{array}$ & $\begin{array}{l}\text { App. } 8 \mathrm{~km} \text {. south- } \\
\text { west of the city } \\
\text { center }\end{array}$ & $\begin{array}{l}\text { App. } 8 \mathrm{~km} \text { south of } \\
\text { the city center on } \\
\text { Kigamboni } \\
\text { peninsula }\end{array}$ & $\begin{array}{l}\text { App. } 13 \mathrm{~km} \text { south of } \\
\text { the city center }\end{array}$ \\
\hline
\end{tabular}


Table 2. Categorization of individual residents according to birth place, region of origin and most recent previous area of residence

\begin{tabular}{|lllllc|}
\hline & Birth place & Region of origin & $\begin{array}{l}\text { Most recent previous } \\
\text { area of residence }\end{array}$ & $\begin{array}{l}\text { Length of } \\
\text { residence in Dar } \\
\text { es Salaam }\end{array}$ & $\begin{array}{l}\text { Head } \\
\text { count }\end{array}$ \\
\hline Direct migrants & $\begin{array}{l}\text { Outside Dar } \\
\text { es Salaam }\end{array}$ & $\begin{array}{l}\text { Outside Dar es } \\
\text { Salaam }\end{array}$ & Outside Dar es Salaam & $\begin{array}{l}0-9 \text { years: } 13 \\
10+\text { years: } 10\end{array}$ & 23 \\
\hline Migrant residential movers & $\begin{array}{l}\text { Outside Dar } \\
\text { es Salaam }\end{array}$ & $\begin{array}{l}\text { Outside Dar es } \\
\text { Salaam }\end{array}$ & $\begin{array}{l}\text { Other areas of Dar es } \\
\text { Salaam }\end{array}$ & $\begin{array}{l}0-9 \text { years: } 8 \\
10+\text { years: } 91\end{array}$ \\
\hline $\begin{array}{l}\text { Non-indigenous residential } \\
\text { movers }\end{array}$ & Dar es Salaam & $\begin{array}{l}\text { Outside Dar es } \\
\text { Salaam }\end{array}$ & $\begin{array}{l}\text { Other areas of Dar es } \\
\text { Salaam }\end{array}$ & Lifelong residents & 24 \\
\hline $\begin{array}{l}\text { Indigenous residential } \\
\text { movers }\end{array}$ & Dar es Salaam & Dar es Salaam & Other areas of Dar es & Lifelong residents & 13 \\
\hline Indigenous non-movers & Dar es Salaam & Dar es Salaam & Only lived in current & Lifelong residents & 13 \\
\hline Total & & & area of residence & \\
\hline
\end{tabular}


Table 3. Distribution of migrants according to motive of migration and age at the time of migration

\begin{tabular}{|c|c|c|c|c|c|c|}
\hline & Work & Specific job & Education & Relations & Other & Total \\
\hline $\begin{array}{l}\text { Migrated as } \\
\text { child } \\
\text { (age 0-14) }\end{array}$ & & $\begin{array}{l}\text { Learn a trade from a } \\
\text { relative (1) }\end{array}$ & $\begin{array}{l}\text { Primary school } \\
\text { (2) }\end{array}$ & $\begin{array}{l}\text { Follow migrant } \\
\text { parents, be taken } \\
\text { care of by relatives } \\
\text { (16) }\end{array}$ & & 19 \\
\hline $\begin{array}{l}\text { Migrated } \\
\text { young } \\
\text { (age 15-30) }\end{array}$ & $\begin{array}{l}\text { "Looking for } \\
\text { life," pursue } \\
\text { opportunities in } \\
\text { the city (28) }\end{array}$ & $\begin{array}{l}\text { Work in relative's } \\
\text { business, learn a } \\
\text { trade from a relative, } \\
\text { work transfer, take } \\
\text { care of a relative's } \\
\text { property (13) }\end{array}$ & $\begin{array}{l}\text { Secondary } \\
\text { studies, } \\
\text { diplomas, short } \\
\text { courses, } \\
\text { university } \\
\text { studies (15) }\end{array}$ & $\begin{array}{l}\text { Follow migrant } \\
\text { spouses, marry a } \\
\text { resident of Dar es } \\
\text { Salaam (20) }\end{array}$ & $\begin{array}{l}\text { Escape } \\
\text { trouble } \\
\text { at home } \\
(1)\end{array}$ & 77 \\
\hline $\begin{array}{l}\text { Migrated as } \\
\text { mature } \\
(\text { age }>30)\end{array}$ & $\begin{array}{l}\text { Pursue new } \\
\text { opportunities in } \\
\text { the city (8) }\end{array}$ & Work transfer (7) & & $\begin{array}{l}\text { Live with children, } \\
\text { seek support from } \\
\text { relatives after a life } \\
\text { crisis (10) }\end{array}$ & $\begin{array}{l}\text { Access } \\
\text { to } \\
\text { services } \\
(1)\end{array}$ & 26 \\
\hline Total & 36 & 21 & 17 & 46 & 2 & 122 \\
\hline
\end{tabular}




\begin{tabular}{|c|c|c|c|c|c|}
\hline & $\begin{array}{l}\text { Head } \\
\text { count }\end{array}$ & $\begin{array}{l}\text { Current } \\
\text { tenure form }\end{array}$ & Livelihood & Characteristic traits & Disaggregated head count \\
\hline Homeowners & 92 & Homeowners & $\begin{array}{l}\text { Well-established, } \\
\text { but varied }\end{array}$ & $\begin{array}{l}\text { Long urban trajectories } \\
\text { with many shifts before } \\
\text { they established as } \\
\text { homeowners in the } \\
\text { periphery }\end{array}$ & $\begin{array}{l}64 \text { migrant residential movers } \\
17 \text { non-indigenous residential } \\
\text { movers } \\
11 \text { indigenous residential movers }\end{array}$ \\
\hline $\begin{array}{l}\text { Fast-mover } \\
\text { homeowners }\end{array}$ & 16 & Homeowners & $\begin{array}{l}\text { Well-established, } \\
\text { many formally } \\
\text { employed }\end{array}$ & $\begin{array}{l}\text { Established as } \\
\text { homeowners in the } \\
\text { periphery either directly } \\
\text { or only 1-3 years after } \\
\text { migrating to the city }\end{array}$ & $\begin{array}{l}9 \text { direct migrants } \\
7 \text { migrant residential movers }\end{array}$ \\
\hline $\begin{array}{l}\text { Prospective } \\
\text { homeowners }\end{array}$ & 16 & $\begin{array}{l}\text { Tenants and } \\
\text { caretakers }\end{array}$ & $\begin{array}{l}\text { Well-established, } \\
\text { but varied }\end{array}$ & $\begin{array}{l}\text { Own land and/or are in } \\
\text { the process of } \\
\text { constructing a house } \\
\text { somewhere else in the } \\
\text { city }\end{array}$ & $\begin{array}{l}6 \text { direct migrants } \\
6 \text { migrant residential movers } \\
2 \text { non-indigenous residential movers } \\
2 \text { indigenous residential movers }\end{array}$ \\
\hline $\begin{array}{l}\text { Non- } \\
\text { homeowners }\end{array}$ & 16 & $\begin{array}{l}\text { Tenants and } \\
\text { caretakers }\end{array}$ & $\begin{array}{l}\text { Well-established, } \\
\text { primarily self- } \\
\text { employed in } \\
\text { informal sector } \\
\text { activities }\end{array}$ & $\begin{array}{l}\text { Not in the process of } \\
\text { consolidating as } \\
\text { homeowners in the city, } \\
\text { though mature-of-age } \\
\text { and with long urban } \\
\text { trajectories similar to the } \\
\text { homeowners }\end{array}$ & $\begin{array}{l}2 \text { direct migrants } \\
13 \text { migrant residential movers } \\
1 \text { non-indigenous residential mover }\end{array}$ \\
\hline $\begin{array}{l}\text { Youths and } \\
\text { adult } \\
\text { dependents }\end{array}$ & 19 & $\begin{array}{l}\text { Live with } \\
\text { relatives or as } \\
\text { tenants }\end{array}$ & $\begin{array}{l}\text { Dependents, } \\
\text { and/or in the } \\
\text { process of } \\
\text { establishing } \\
\text { independent } \\
\text { income streams }\end{array}$ & $\begin{array}{l}\text { Not in the process of } \\
\text { establishing as } \\
\text { homeowners, because } \\
\text { they are youths or adult } \\
\text { dependents }\end{array}$ & $\begin{array}{l}6 \text { direct migrants } \\
9 \text { migrant residential movers } \\
4 \text { non-indigenous residential movers }\end{array}$ \\
\hline $\begin{array}{l}\text { Indigenous } \\
\text { non-movers }\end{array}$ & 13 & Homeowners & $\begin{array}{l}\text { Fishing and self- } \\
\text { employed in } \\
\text { informal sector } \\
\text { activities }\end{array}$ & $\begin{array}{l}\text { Have lived in the same } \\
\text { case study area most of } \\
\text { their life }\end{array}$ & 13 indigenous non-movers \\
\hline Total & 172 & - & - & - & - \\
\hline
\end{tabular}




\begin{tabular}{|lcccc|}
$\begin{array}{l}\text { Table 5. Distribution of individual residents in relation to the number of residential areas they have resided in within } \\
\text { Dar es Salaam }\end{array}$ & 1 area & 2 areas & $\mathbf{3}$ or more areas & Total \\
\hline Homeowners & - & 21 & 71 & 92 \\
\hline Fast-mover homeowners & 9 & 7 & 7 & 16 \\
\hline Prospective homeowners & 6 & 3 & 9 & 16 \\
\hline Non-homeowners & 2 & 5 & 2 & 19 \\
\hline Youths and adult dependents & 6 & 11 & - & 13 \\
\hline Indigenous non-movers & 13 & 47 & 89 \\
\hline Total & 36 & - & 72 \\
\hline
\end{tabular}

\begin{tabular}{|c|c|c|c|c|c|}
\hline & $\begin{array}{l}\text { Consolidated } \\
\text { central area }\end{array}$ & $\begin{array}{l}\text { Consolidated } \\
\text { peripheral area }\end{array}$ & $\begin{array}{l}\text { New developing } \\
\text { peripheral areas }\end{array}$ & $\begin{array}{l}\text { Outside Dar es } \\
\text { Salaam }\end{array}$ & Total \\
\hline Homeowners & 73 & 11 & 8 & - & 92 \\
\hline Fast-mover homeowners & 3 & 2 & 2 & 9 & 16 \\
\hline Prospective homeowners & 6 & 1 & 3 & 6 & 16 \\
\hline Non-homeowners & 11 & 3 & - & 2 & 16 \\
\hline Youths and adult dependents & 6 & 3 & 2 & 8 & 19 \\
\hline Indigenous non-movers & - & - & - & - & 13 \\
\hline Total & 99 & 20 & 15 & 25 & 172 \\
\hline
\end{tabular}




\begin{tabular}{|c|c|c|c|c|c|c|}
\hline & \multicolumn{3}{|c|}{ Staying in Dar es Salaam } & \multicolumn{2}{|c|}{ Leaving Dar es Salaam } & \multirow[b]{2}{*}{ Total } \\
\hline & $\begin{array}{l}\text { Expect to live } \\
\text { permanently } \\
\text { in their } \\
\text { current home }\end{array}$ & $\begin{array}{c}\text { Consider } \\
\text { shifting to } \\
\text { another area in } \\
\text { Dar es Salaam }\end{array}$ & $\begin{array}{l}\text { Plan to shift } \\
\text { to another } \\
\text { area in Dar es } \\
\text { Salaam }\end{array}$ & $\begin{array}{l}\text { Consider } \\
\text { leaving Dar es } \\
\text { Salaam }\end{array}$ & $\begin{array}{c}\text { Plan to } \\
\text { leave Dar es } \\
\text { Salaam }\end{array}$ & \\
\hline Homeowners & 62 & 14 & 6 & 5 & 5 & 92 \\
\hline Fast-mover homeowners & 12 & - & 1 & 2 & 1 & 16 \\
\hline Prospective homeowners & - & 1 & 15 & - & - & 16 \\
\hline Non-homeowners & - & 12 & - & 2 & 2 & 16 \\
\hline $\begin{array}{l}\text { Youths and adult } \\
\text { dependents }\end{array}$ & 1 & 13 & - & 4 & 1 & 19 \\
\hline Indigenous non-movers & 10 & - & - & 3 & - & 13 \\
\hline Total & 85 & 40 & 22 & 16 & 9 & 172 \\
\hline
\end{tabular}

